\title{
ADAPTATION OF NEIGHBOURHOOD PLANNING TO CLIMATE CHANGE IN THE CONTEXT OF LOW INCOME NEIGHBOURHOODS
}

\author{
Developed under the JnNURM scheme for Hyderabad
}

\author{
Santhanm Kumar ${ }^{1}$, Malakapalli Venkata Janardhan Rao ${ }^{2}$ \\ Professor, Dept. of Architecture, SPA, JNAFA University, Hyderabad, India \\ skumarjnafau@gmail.com
}

Assoc. Prof. School of Architecture, Dayanandasagar Academy of Technology \& Management, Bangalore, India. studiozeninc@gmail.com

\begin{abstract}
This work is focused on studying the adaptation policies required to planning of neighborhood at local scale of Hyderabad Metropolitan Region. The objectives include 1) Study, understand and establish if climate change is happening at all in the context of Hyderabad' Metropolitan Region and its impact on the Neighborhood planning. 2) If at all climate change happening, identify the factors/Phenomena causing climate change. 3) Estimating the effects of climate change with respect to neighborhood planning, and proposing Viable solutions acceptable by the Existing neighborhood/community.
\end{abstract}

Keywords: Climate; Neighbourhood Planning; Building Byelaws; Urban Heat Islands.

\section{INTRODUCTION}

Scientific opinion is now unanimous that global temperatures are likely to continue to rise with concomitant extreme weather patterns and events. There is a protean body of scientific literature available on global warming and climate change, which is affecting urban living in every respect from 'heat islands', continuous light and sea level changes as well as severe droughts and floods paralyzing urban areas. It has emerged as the biggest developmental challenge for the planet, particularly on the poor. Urban planning implications are reflected in buildings, street and community design for more environmentally sustainable cities. As these changes cannot be anticipated and need to be examined with a new paradigm for urban problem solving. Communities developed under schemes like JnNURM offers a scope to develop a synergetic approach to building resilience to tackle climate change at Neighborhood level.

\section{METHODOLOGY}

Quantitative data from Meteorological station at regional level are collected done for two weather stations of Begumpet located in the Metropolitan region of Hyderabad and Medak which is located in the periphery of Metropolitan Region for a period of 30 years to identify \& understand the climate changes at regional level by comparative analysis. Qualitative data in the form of Perception studies are conducted to understand the socio- economic in terms of distance to work place \& physical comforts in terms of space requirements, thermal comforts of the residents living in settlements built under slum development program were studied. The climate change projections from various sources viz IPCC A1, A2, scenarios were studied to understand the possible change in temperature and extreme events for the region of Hyderabad.

\section{STUDY AREA}

These data sets are used to explore the shortcomings and possibilities in the JnNURM housing scheme proposed project at Abdulapurmet, adjacent to NH 9, Hayatnagar mandal, Rangareddy district, Hyderabad.

\section{ANALYSIS}

Hyderabad's Climate data for the last 60 years (1951-2009, from Begum pet Weather Station) had been analysed to understand if there is a change in the parameters like, mean maximum/minimum temperatures, wind speed, relative humidity, rainfall etc. Then these were compared to the global mean temperatures and highest temperatures recorded in the last 130 years, published by NASA-GISS.

1. It was found out that the global temperatures were increasing by about $1^{\circ} \mathrm{C}$ to $2^{\circ} \mathrm{C}$ in a decade (source: NASA- GISS), whereas comparative study of climate of Hyderabad based on (1951-80, base period and 19802009) of averaged mean Maximum temperature during period showed that temperature has risen by $4^{\circ} \mathbf{C}$, in the month of March and $\mathbf{1}^{\circ} \mathbf{C}$ in December and January. Mean Minimum Temperatures have increased by $1.4^{\circ} \mathrm{C}$ in January and $\mathbf{1}^{\circ} \mathrm{C}$ in December. Evening Humidity has increased by $6 \%$ in the month of March and May. Average wind speed had decreased by $6 \mathbf{k m} / \mathbf{h r}$. in the month of June and July causing much discomfort and increasing Energy Requirements. This data was also compared against the nearby rural area called Medak's 
temperature recordings. But there was no such huge increase in temperatures in the Medak rural area.

2. The increase in mean maximum temperatures, evening humidity and decrease in wind speed, and marginal increase in rainfall (Hyderabad's rainfall follows the $\mathbf{1 3 2}$ year cycle of southwest monsoon, study of this data reveals that the change in rainfall is cyclical phenomena ) establishes that the reasons for Hyderabad's increase in temperature is because of Urban Heat Islands, which are a result of not only because of density and built form but also because of planning of new developments without taking into consideration, the topography, prevailing wind directions, and preservation of water bodies.

3. With the aim of studying and understanding Climate Change to Adapt at neighbourhood level, a socioeconomic survey was conducted with 286 households, near Khairatabad. This is because of the similarity of neighbourhood to that of the neighbourhood's being developed under JnNURM scheme to understand their perception to climate change, identify the problems in the existing neighbourhood. Two important findings form the survey was that the average size of the family was about 6 people, were living in Mere $30 \mathrm{Sq}$. M area and the place of work from where the quarters were allotted is too far and sometimes takes about 1 hour to travel.

4. To Estimate the effects of Climate Change Predictions by four reputed institutes/Universities' across the Globe have been used. They are 1) National Climate Change Policy, India. (Based on IPCC A2[1] Scenarios). 2) IPCC Climate Change projections. 3) Climate Change projections of Hadley Centre, U.K. 4) United Nations University, Bonn climate change projections specifically for Hyderabad. The outcome of all these projections/Predictions indicated that there will be extreme events like more than $160 \mathrm{~mm}$ of precipitation per day (like for example, August 2010). Average Number of days with night temperatures with more than $\mathbf{2 7}^{\circ} \mathrm{C}$ will triple by 2050 . Mean annual temperature may go up by $+5^{\circ} \mathrm{C}$, for Hyderabad By 2010. All this would result in Heat Waves, Stress on Water Availability, and Increased Extreme Events (for both Heat \& Cool Temperature.)

5. Urbanisation had led to the drastic changes in Land use and Land cover changes over the past thirty years in many cities across the world. As a result water bodies are lost and traditional methods of cooling the city by evaporation from water bodies and evapotranspiration from tree cover and changes in albedo have led to the formation of Heat islands and urban canyons.

6. Auto Cad Ecotect Analysis software was used to simulate the year around shadows, incident solar radiation, to arrive at best possible orientation of buildings, with respect to Sun Angles. It was found out that the best orientation would be to orient the Long side of the Building on North-South Cardinal Points. It was further found out that most of the wind direction in Hyderabad was in East-West Axis; hence most of the openings are suggested in these cardinal points to take advantage of Air movements. All this is at Building level.

\section{RECOMMENDATIONS}

- A minimum built up area of 45 square meters

- Balconies provided on the West side to cut of direct radiation on the western walls.

- Orient the Long side of the Building on North-South Cardinal Points at 12 degrees angle towards South.

- At Site planning level, Trees are suggested @ one for every 100 SQ.M, also, trees like Azardiracta Indica, Saeiamia saman, have been suggested which will help in evapotranspiration and with its evergreen thick foliage gives much need relief in the sun during summers.

- Rainwater Harvesting, Cool Roofs, Buildings orientation to proper solar angles, increasing the evapotranspiration through planting specific species of trees, Providing a minimum of 45 Sq.M of built up area, Planning of Settlement's close to work rather than gentrification of City cores, are some of the technical solutions these thesis purposes.

- Neighborhood planning must consider likely increase in heat waves.

- Geometric variables and construction variables should be considered in planning and designing buildings in the neighborhood.

- Passive methods of cooling should be adopted.

However more than technical solutions, Climate Change Adaptation Measures have to be taken by both, structured and not-structured forms of Planning especially when dealing with the economically weak and climate vulnerable societies. Policies need to be framed incorporating Climate Change/ Climate Responsive designs in BUSP(Basic services for Urban Poor) when taking up Urban Renewal through JnNURM(Jawaharlal Nehru Urban Renewal Mission).

\section{CONCLUSIONS}

Study found some adaptation measures such as forest protection, utilization of marginal lands by planting trees and grasses, crop diversifications in their farming practices. However, poor and marginalized groups were unaware regarding climate change impacts and adaptation measures. Thus, these measures were found to be event specific based on local knowledge and innovations, and not actually to cope with the impacts of climate change.

India is a developing nation with technological and monetary constraints, also the Ecological, Carbon and Food print of India is very low when compared against developed countries. So adaptation to climate change is the best strategy for a developing country like India.

\section{ACKNOWLEDGMENT}

I thank all my colleagues, friends, teachers and consultants who helped me throughout my endeavor. 


\section{REFRENCES}

[1] IPCC Climate Change Report.

[2] UN-Habitat, Cities and Climate Change:Global Report on Human Settlements, 2011

[3] UN-Habitat, Planning for Climate Change, A Strategic value based approach for urban Planners

[4] UN-Habitat, Local leadership for climate change action

[5] UNEP, Mainstreaming Climate change adaptation into

Development Planning: A guide for practitioner

[6] Lamb, H, Changing Climate, Routledge, 2011

[7] Dam, Jan C. Van. Impacts of Climate Change and

Climate variability. Cambridge University Press

[8] Dubash, Navroz K, Hanbook of Climate Change and India, Development, Politics and ?governance, Routledge, 2011 